\title{
Learning Strategies Model to Enhance Thai Undergraduate Students' Self-Efficacy Beliefs in EIL Textual Reading Performance
}

Jiraporn Kakaew*, Anamai Damnet

Kasetsart University Kamphaeng Saen Campus, Thailand

Correspond Author: Jiraporn Kakaew, E-mail: jirameow@gmail.com

\section{ARTICLE INFO}

Article history

Received: August 15, 2017

Accepted: October 19, 2017

Published: December 30, 2017

Volume: 8 Issue: 6

Advance access: December 2017

Conflicts of interest: None

Funding: None

Key words:

Learning Strategies Model,

Thai Undergraduate Students,

Self-Efficacy Beliefs

EIL Textual Reading Performance

\begin{abstract}
This classroom based research of a learning strategies model was designed to investigate its application in a mixed-ability classroom. The study built on Oxford's language learning strategies model $(1990,2001)$ and fulfilled it with rhetorical strategies to accommodate challenges encountered in the paradigm of English as an international language (EIL). The main purpose aimed to explore Thai students' self-efficacy beliefs (SE) in reading different texts regarding both Western and Asian styles after receiving a strategies-based training. In this research, thirty-three first-year undergraduate students majoring in English Education were purposively selected as participants for the training. The data from pre and post questionnaires focusing on students' self-efficacy beliefs was analyzed using descriptive statistic and thematic analysis. The results revealed that students believed to have higher efficacy in EIL textual reading after learning strategies-based training. The presentation will also include discussion and suggestion in implementing rhetorical-language learning strategies in the classroom.
\end{abstract}

\section{NTRODUCTION}

Self-efficacy beliefs (SE) are generally defined as humans' judgment regarding their abilities to perform actions that influences on their lives (Bandura, 1998). Bandura, 1986, cited in Riding and Rayner, 2001 p.251 identifies self-efficacy as much more consistent predictor of behavior than any other closely related variables. Similarly, Siritararatn (2013) proposes SE is a key determiner of students' learning achievement and Mastan and Maarof, 2014 illustrate that it is a strong indicator of language performance. It is also revealed as the strongest predictor of academic performance (Bembenutty, 2009). That is the students who have high self-efficacy make better efforts than the students who have low self-efficacy (Bandura, 1997, 1998; Zimmerman 2000). Since self-efficacy appears as one of the most influential factors for L2 learning, it is very important for the teacher to develop the students' self-effica y (Raoofi et al, 2012) which can be promoted through learning strategies (Khajavi and Ketabi, 2012). Previous studies suggest the possibility to enhance SE with Thai students who study English as a foreign language (EFL) (Siritararatn 2013; Ngoksimma, 2014).

Significantl, English nowadays is used among natives and non-natives and McKay, 2002 identifies this situation as English as an international language (EIL). In spite of the fact that Thailand has joined the ASEAN community and noticeably several non-natives using English possibly increase, EFL learning and teaching is still related to native-like competence (Jindapitak, 2014). In such cases, the principle of English learning and teaching in Thailand needs to be reviewed and fulfilled in order to facilitate students to learn a variety of situations. This paper will challenge the concept of EIL learning and teaching to promote Thai self-efficacy beliefs (SE) in reading different texts both Western and Asian styles through engaging learning strategies model.

\section{LITERATURE REVIEW}

\section{Learning Strategies and Self-Efficacy Beliefs}

Learning strategies in second language acquisition (SLA) are studied widely and language learning strategies (LLSs) characteristics mostly include cognitive strategies, metacognitive strategies, social strategies, effective strategies and communication strategies (O'Malley and Chamot, 1990; Oxford, 1990, 2001; Cohen, 2000; Brown, 2007). Cognitive strategies facilitate the learners to think and focus on the language events that they encounter directly. Metacognitive strategies involve learners' planning, controlling and managing themselves to succeed in knowledge of language. 
Social strategies stimulate learners to interact and participate with others and affective strategies reflect the learners' attitudes, motivation and emotions in language learning. LLSs are cited and put them in English class to promote language learners to succeed in language learning. It is inevitably to study students' self-efficacy when students' learning, academic performance and motivation is examined (Pajares and Urdan, 2006). It is revealed that providing students with learning strategies can support them to increase their self-efficacy beliefs (Ma golis and McCabe, 2006) Learning strategies also promote the students' self-efficacy beliefs in English classroom (Chularut and DeBacker (2004; Khajavi and Ketabi, 2012).

\section{Reading Self-Efficacy Beliefs}

Recently, SE has been raised in discussions of reading English classroom regarding the effectiveness of reading strategies on enhancing their self-efficac. The significant studies evolve around the topics of the students' effectiveness of reading strategies on enhancing their self-efficacy (Chan and Lam, 2010; Khajavi and Ketabi, 2012), the positive relationship between the students' self-efficacy and their strategy uses (Li and Wang, 2010), the relationship between the students' self-efficacy beliefs and their learning achievements (Naseri and Zaferanieh, 2012). In the study by Chan and Lam (2010), participants who receiving formative feedback show higher self-efficacy than those receiving summative feedback and that self-referenced feedback is more beneficial to students' self-efficacy than norm-referenced feedback. Khajavi and Ketabi (2012) mention that the students studying with concept mapping have greater self-efficacy than the students in control group. Li and Wang (2010) illustrate reading self-efficacy has significantly positive relationship with the use of reading strategies. Highly self-efficacious readers show more use of reading strategies than those who had low self-effic cy. Naseri and Zaferanieh, (2012) present there are significan strong positive correlation between reading self-efficacy beliefs and reading comprehension and also between reading self-efficacy beliefs and reading strategies use

The research suggests that there is a positive relationship between learning strategies and self-efficacy in English reading classrooms; however, there is no published research to date that study the effects of learning strategies on the students' self-efficacy beliefs in EIL textual reading performance although intercultural knowledge is a necessary content to be considered and put in English classroom. As it is mentioned earlier, this study is the first attempt to explore the effectiveness of learning strategies on the students' self-efficacy in the paradigm of EIL learning and teaching with the aim to answer the following research questions.

\section{Research Questions}

1) What are Thai students' beliefs in terms of their self-efficacy in EIL textual reading?

2) How does reading the different texts written in Western and Asian styles affect Thai students' self-efficacy beliefs in their EIL textual reading?

\section{METHODOLOGY}

\section{Participants}

This classroom based research was conducted with 33 first-year students as the purposive section and whose majors were English Education students. They enrolled in the preparatory course for English as an International Language (EIL) during the second semester of academic year, 2015.

\section{RESEARCH INSTRUMENTS}

\section{1) Learning Strategies Model}

Oxford's classification of language learning strategies (LLSs) $(1990,2001)$ was selected as most appropriate to be adapted for use in the present study. Specificall, this model was selected because it covered both direct and indirect learning and could facilitate improving the students' reading performance. Further, in the present study, the model was adapted and integrated with an EIL learning and teaching approach (McKay, 2002) to support students to read different texts in a variety of rhetorical styles, specifically Western and Asian rhetorical writing styles. After the model was developed, it was tested and approved by five experts, who rated the model on a scale of $1-5$, with the model achieving an overall validation rating of 4.9. Adapted learning strategies (LLSs) model utilized in the current study is presented in Figure 1.

To demonstrate the language learning strategies (Oxford, $1990,2001)$ and clarify a rhetorical-language learning strategies model adapted to the students' needs in the paradigm of EIL, these are presented in Table 1.

\section{2) Texts for Reading}

Several informational texts were selected as authentic reading materials from both Western and Asian sources, such as from English magazines, Singaporean magazines, the South China Morning Post, China Daily and Vietnamese magazines. These reading passages were mostly selected from online sources and adapted to the students' interests as well as being related to the course curriculum. Five experts proofed the levels of vocabulary difficulty and the interestingness of the reading passages (Suwantharathip, 2012). The overall scores of texts were calculated utilizing the Index of term objective congruence (IOC) procedure for determining the content validity. The results showed that all texts were valid as the proposed items scored 1.00. Then, the model and reading materials were tried out, adjusted appropriately to the target group, and finally implemented in the classroom

\section{3) Pre-Post Questionnaire of Self-Efficacy Beliefs (SE)}

A self-efficacy questionnaire adapted from Ghonsooly and Elahi (2010) and Wang et al. (2013) was developed to explore the students' SE in EIL textual reading performance before and after undertaking training in learning strategies. The questionnaire included both quantitative and qualitative data, with the questionnaire divided into three parts: 


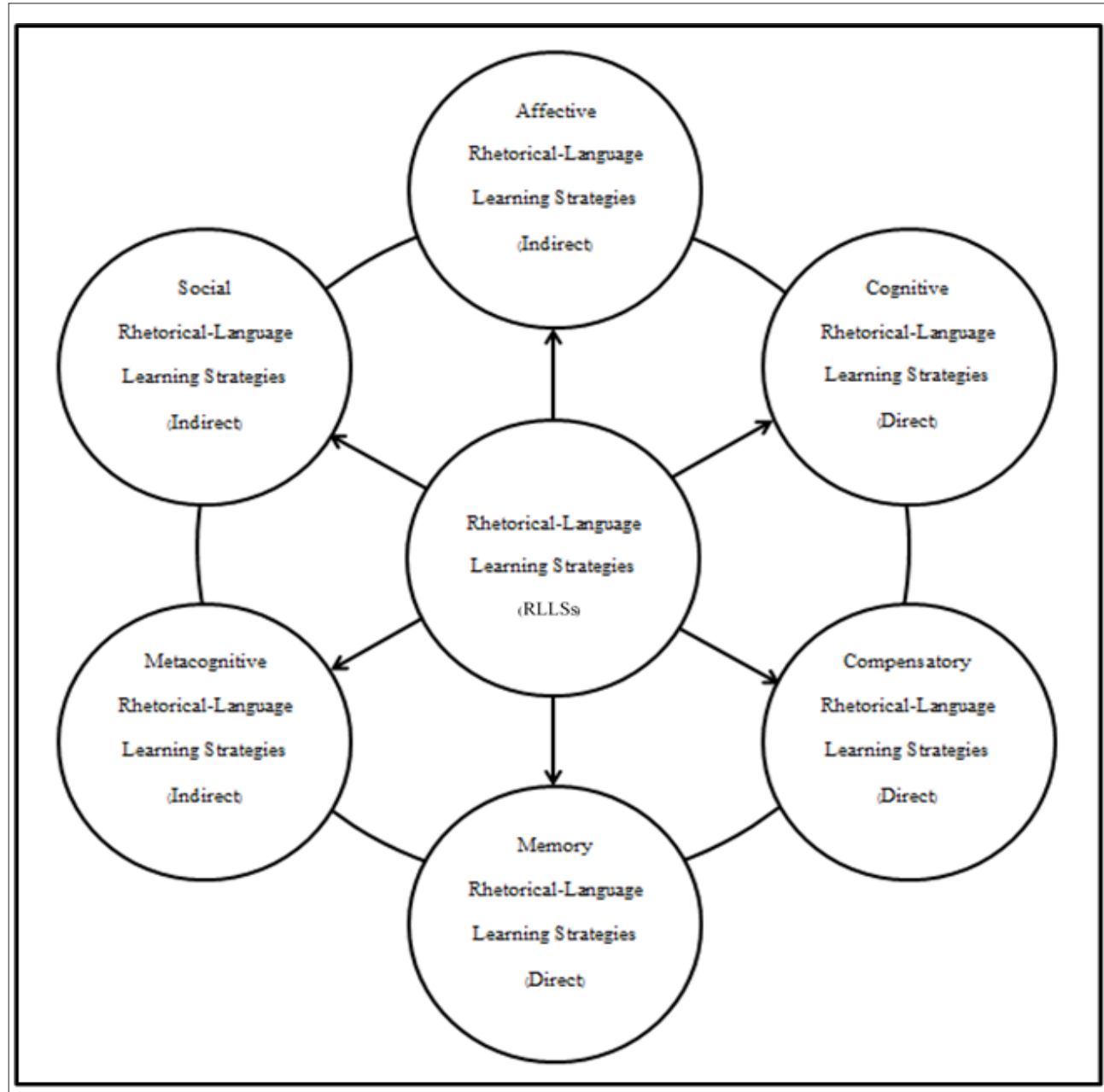

Figure 1. Adapted learning strategies (LLSs) model (Oxford, 1990, 2001)

Table 1. Language learning strategies (Oxford, 1990, 2001) and the adapted model

\section{Language Learning Strategies}

(Oxford, 1990, 2001)

\begin{abstract}
Affective strategies to enhance the learners' attitudes,
motivation, and emotions in language learning and using.
\end{abstract}

Cognitive strategies to encourage the learners to think and focus on the language events that they encounter directly.

Compensatory strategies to guide the students to compensate and reach for successful language learning and using.

Memory strategies to facilitate the students to think, mind, and recall themselves items for language learning and using.

Metacognitive strategies to involve learners' in planning, controlling, and managing themselves to enable them to succeed in language learning.

Social strategies to stimulate learners to interact and participate with others in language learning.
Rhetorical-Language Learning Strategies (Adapted Model)

Affective strategies to support the students by reflecting their attitudes and motivation and by opening their minds to read various styles of texts.

Cognitive strategies to help the students to recognize language directly and to analyze rhetorical styles of writing.

Compensatory strategies to help the students to read successfully, together with guessing rhetorical styles.

Memory strategies, such as mind-mapping, to stimulate the students to recall the different cultural styles and writing patterns.

Metacognitive strategies to support the students planning, controlling, and managing themselves in their approach to language and rhetorical styles.

Social strategies to enhance the students to interact, participate with others, and discuss their learning in terms of English language and rhetorical patterns 
Part 1: This part covered the students' demographic information, such as their gender and age, as well as their English learning experience and English proficienc .

Part 2: A rating scale to assess the students' self-efficacy beliefs was presented to determine the students' SE level of reading EIL texts before and after undertaking training on the learning strategies, designed in accordance with the Likert Scale: 1.00-1.49 = strongly disagree; $1.50-2.49=$ disagree; $2.50-3.49=$ neutral; $3.50-4.49=$ agree; $4.50-5.00=$ strongly agree

Part 3: This part asked some questions that gave the students the opportunity to answer and to give extra details to explain their answers. These questions were: 1) Do you have the same self-efficacy beliefs in your reading performance when you read the texts written in Western and Asian styles? 2) As you read the texts written in the form of Western deductive style, do you maintain your self-efficacy beliefs in your reading performance, and if so, how? 3) As you read the texts in the form of Asian inductive style, do you maintain your self-efficacy beliefs in your reading performance, and if so, how? Opportunity was also provided to make other comments. These responses were grouped by themes for the final analysis.

Importantly, this questionnaire was evaluated by the experts for proofing the content validity, whereby the experts marked each response as: appropriate $(+1)$, not sure $(0)$, or not appropriate $(-1)$. The overall scores were calculated utilizing the Index of term objective congruence (IOC) procedure for determining the content validity. The results showed that all the responses were valid as the proposed items scored 1.00. Thus, the questionnaire was considered validated. It was then utilized in a pilot-test with 30 students and checked for internal consistency reliability via Cronbach alpha function. Here, the value needs to be higher than 0.7 , and preferably closer to 0.9 . This questionnaire for $\mathrm{SE}$ in reading scored 0.90 , and thus was considered as having acceptable internal consistency.

\section{Data Collection Procedure}

This study was designed in three phases as follows:

Phase 1: Planning - In this phrase, first the SE questionnaire underwent validity and reliability proofing. Pre-training questionnaires were distributed to all the students to explore their reading performance, and a learning strategies model was prepared as well as lesson plans and the appropriate reading materials. The test class included mixed-ability students, so a mixture of previous learning grades and student performance in the language proficiency test: a TOEFL paper-based test (Educational Testing Service, 2003) was used to analyze their individual language performances before training, and then appropriate reading materials, including a learning strategies model, were designed appropriately for all the students. Apparently, explicit strategy training was prepared to support the students to get the most out of their reading EIL lessons. Through illustrating the rhetorical-language learning strategies and presenting an effective thinking process to the students, together with using several strategies for the different reading tasks, the researcher was able to effectively evaluate the students on their self-efficacy beliefs in EIL textual reading. This course lasted a total of 16 weeks and the students were also tasked with using their learning strategies to aid their reading development without teacher supervision during week 11-15.

Phase 2: Strategies Training - Every student was trained with 10 lessons in 40 hours to raise their awareness of rhetorical-language learning strategies (RLLSs) in EIL textual reading, including 4 lessons in 16 hours to do tasks without teacher supervision. Importantly, a new lesson plan comprising teaching a set strategy was launched each week. Before starting class, the teacher needed to clarify the reasons behind their EIL performance and to assess the most appropriate affective strategies to promote the students to open their minds to reading various styles of texts. The students first learned about organization and rhetorical styles in texts through learning about cognitive strategies. Next, when the students got to know about the different styles of texts, they learned how to use compensatory strategies to read the content and to guess the rhetorical styles After that, they practiced memory-related strategies to recall the different cultural styles of texts, and then learned metacognitive strategies to stimulate them to plan, control, and evaluate both rhetorical and overall language use. Finally, social strategies were discussed in the classroom. The teacher demonstrated how to use each strategy and the students tried to follow the steps to use the strategy to aid their reading.

\section{Phase 3: Assessment and Evaluation}

After the students had completed the learning strategies training course, they were provided with a postcourse questionnaire during the last week of this semester covering questions about the students' SE in reading after having received the learning strategies training. Then, the students' pre- and post-training questionnaires were analyzed and the results compared. The students' SE in reading EIL texts was evaluated to investigate whether their $\mathrm{SE}$ in reading was higher or not after having received the learning strategies training. The questionnaire responses were considered together with the data from the open-ended questions revealing views on the students' approaches and views on the different texts written in the Western and Asian styles, as well as other useful comments made by the students.

\section{Data Analysis}

The data analysis was performed with a statistical method in order to compare the students' self-efficacy beliefs before and after attending the learning strategies training through their responses given to a set of questions presented in pre- and post-training questionnaires. Descriptive analysis was used. Also, a thematic analysis (Braun and Clarke, 2006) was carried out for the open-ended responses in the final part of the questionnaires to clarify the participants' reading self-effic cy beliefs with the different texts written in the Western and Asian styles. 


\section{RESEARCH RESULTS}

The results are presented here in three main parts relating to the structure of the questionnaire: part 1) covers the students' demographic information, part 2) covers the descriptive statistical information related to the students' SE in EIL textual reading, and part 3) provides transcriptions of some of the open-ended responses of the students' regarding reading their SE of reading the different texts written in the Western and Asian styles. Therefore, the following findings were revealed:

Part 1: 33 students participated in the class. $85 \%$ were female and $15 \%$ were male. All aged between 18 and 20 years old. The class comprised students of mixed abilities, with 5 classed as high-ability students, 17 mid-ability students and 11 low-ability students, respectively.

Part 2: Table 2 presents the descriptive statistics from analyzing the responses to research question 1 (What are Thai students' beliefs in terms of their self-effic cy in EIL textual reading?). The mean scores of their responses were interpreted according to a five-point Likert Scale:

$\begin{array}{lll}1.00-1.49 & = & \text { strongly disagree } \\ 1.50-2.49 & = & \text { disagree } \\ 2.50-3.49 & = & \text { neutral } \\ 3.50-4.49 & = & \text { agree } \\ 4.50-5.00 & = & \text { strongly agree }\end{array}$

Table 3. displays the students' self-efficacy beliefs (SE) in EIL textual reading performance before and after receiving training in learning strategies. The data was summarized and clarified in three groups depending on how much they agree with the statement:

1) Disagree to agree, such as "I care about achieving high scores in my reading course."; "I do not have any problems with reading comprehension."; "I have the ability to focus all my concentration on reading English texts in both Western and Asian styles."; "Reading English texts is not stressful for me."

2) Neutral to agree, such as "I believe that I can improve my course grades by practicing reading English texts more."; "I can improve my reading comprehension skills."; "I believe that my proficiency in reading English texts improves every day."; "I can read and understand the English texts in the printed and online ma-

Table 2. Students' self-efficacy beliefs in EIL textual reading performance

\begin{tabular}{|c|c|c|c|c|c|c|}
\hline \multirow{2}{*}{$\begin{array}{l}\text { Statement } \\
\text { Reading } \\
\end{array}$} & \multicolumn{3}{|c|}{ Pre } & \multicolumn{3}{|c|}{ Post } \\
\hline & $\mu$ & $\sigma$ & Level & $\mu$ & $\sigma$ & Level \\
\hline $\begin{array}{l}\text { 1. I have the ability to focus all my concentration on reading English texts in } \\
\text { both Western and Asian styles }\end{array}$ & 2.48 & 0.91 & Disagree & 3.82 & 0.69 & Agree \\
\hline 2. I believe that my proficiency in reading English texts develops every day. & 2.55 & 1.00 & Neutral & 4.06 & 0.80 & Agree \\
\hline 3. I can improve my reading comprehension skills. & 3.42 & 0.97 & Neutral & 4.21 & 0.70 & Agree \\
\hline 4. Reading English texts is not stressful for me. & 2.00 & 0.75 & Disagree & 3.70 & 0.81 & Agree \\
\hline
\end{tabular}

Table 3. Students' self-efficacy beliefs in EIL textual reading performance (cont.)

\begin{tabular}{|c|c|c|c|c|c|c|}
\hline \multirow{2}{*}{$\begin{array}{l}\text { Statement } \\
\text { Reading }\end{array}$} & \multicolumn{3}{|c|}{ Pre } & \multicolumn{3}{|c|}{ Post } \\
\hline & $\mu$ & $\sigma$ & Level & $\mu$ & $\sigma$ & Level \\
\hline $\begin{array}{l}\text { 5. My teacher believes that I am proficient in reading } \\
\text { comprehension. }\end{array}$ & 2.52 & 0.97 & Neutral & 3.67 & 0.70 & Agree \\
\hline $\begin{array}{l}\text { 6. I enjoy practicing reading English texts with others } \\
\text { who are proficient at reading English. }\end{array}$ & 3.12 & 0.86 & Neutral & 3.88 & 0.82 & Agree \\
\hline $\begin{array}{l}\text { 7. I believe I can improve my course grades by } \\
\text { practicing reading English texts more. }\end{array}$ & 3.33 & 1.05 & Neutral & 4.24 & 0.67 & Agree \\
\hline $\begin{array}{l}\text { 8. When the teacher asks questions in my reading } \\
\text { class, I always volunteer to answer. }\end{array}$ & 1.58 & 0.87 & Disagree & 3.18 & 1.01 & Neutral \\
\hline 9. I am a good student in my English reading class. & 1.64 & 0.65 & Disagree & 3.21 & 1.05 & Neutral \\
\hline $\begin{array}{l}\text { 10. I do not have any problems with reading } \\
\text { comprehension. }\end{array}$ & 2.30 & 0.68 & Disagree & 3.94 & 0.82 & Agree \\
\hline $\begin{array}{l}11 . \text { I care about achieving high scores in my reading } \\
\text { course. }\end{array}$ & 1.52 & 0.71 & Disagree & 3.97 & 0.95 & Agree \\
\hline $\begin{array}{l}\text { 12. I can finish my English reading homework } \\
\text { independently. }\end{array}$ & 2.73 & 0.88 & Neutral & 3.79 & 0.96 & Agree \\
\hline $\begin{array}{l}\text { 13. I can read and understand the English texts in the } \\
\text { printed and online materials. }\end{array}$ & 2.91 & 0.84 & Neutral & 4.00 & 0.80 & Agree \\
\hline Total Average & 2.47 & 0.13 & Disagree & 3.82 & 0.13 & Agree \\
\hline
\end{tabular}

Source: Adapted from Ghonsooly and Elahi (2010); Wang, et al. (2013) 
terials."; "I enjoy practicing reading English texts with others who are proficient at reading English."; "I can finish my English reading homework independently."; "My teacher believes that I am proficient in reading comprehension."

3) Disagree to neutral, such as "I am a good student in my English reading class."; "When the teacher asks questions in my reading class, I always volunteer to answer."

Overall, the students' self-beliefs in their EIL textual reading performance before they received the training was low, tending to disagree with the questionnaire statements, with an average ranking score of 2.47; while after receiving the training, they agreed more with the statements, scoring on average ranking score of 3.82. Therefore, the results based on the descriptive analysis showed that these students' SE in EIL textual reading performance after receiving training was improved.

In addition to the statistics data, the students' open-ended responses in the next part were assessed to clarify research question 2 (How does reading the different texts written in Western and Asian styles affect Thai students' self-efficacy beliefs in their EIL textual reading?)

Part 3: Transcribing the students' open-ended responses regarding their SE beliefs in reading different texts regarding Western and Asian styles

The students' SE belief in their reading performance after receiving the learning strategies training was, on average, higher than before they received the training. In the case of the differences in rhetorical styles between Western and Asian texts, all students' judgments' of their SE in the different texts was reflected in their reading behavior, attitudes, and motivation, with such responses being given among all the classes of students, i.e. those of high, mid, and low abilities.

\section{Reading Behavior}

Every student reported improved their SE in reading and understanding both rhetorical writing styles, namely Western deductive and Asian inductive patterns; however, given the text differences, all of them took different amounts of time to read the different texts, with most of them feeling a benefit from discussing the text with their friends while reading the Asian texts.

\section{Taking different amounts of time to read and comprehend the different texts}

All of the students attempted to read several text types from different country sources and styles. Regarding the Western style, the students could generally easily determine the main ideas and supporting details. When they read through from the first to the last paragraph, they were able to summarize their understanding within an appropriate time and were able to comprehend the writer's main purpose; stating, for example, Nancy said, "In the past, I had some problems reading English texts; however, at present, I can read them quickly, especially Western texts."; Ureka said "I don't take as much time reading the Western rhetorical style due to the use of direct statements."
However, when they read the texts from Asian sources, they had to read the text several times in order to make sure of comprehending the text because the main ideas behind the text are not usually given in the first paragraph and the text did not precisely show the writers' ideas clearly; with the students stating, for instance, Jenny said "I tried to persist longer although I was faced with some circular thinking patterns in the inductive style of texts,"; Tony said "While I study different rhetorical styles in reading texts, it makes me reflect my different reading behavior, especially my need to take a lot of time to read Asian texts.

\section{Discussing with their friends while reading the Asian texts}

Most of the students liked to share and discuss their understanding of the texts with their friends while reading the Asian texts when they had an opportunity to do such thing. For Western texts, they shared understanding of the contents after they had finished reading; stating, for example, Patty said "As I read texts written with the Asian inductive style, I liked to read with my friends because this helps me to better understand."; Yaya said "To successfully read both texts, I used similar strategies for reading; however, I preferred reading and discussing the text together with my friends while reading the Asian inductive style to raise my confidence in understanding the text." In this case, some students preferred to read independently because they were confident about using the learning strategies for reading and understanding the texts.

\section{Attitudes}

All of the students were more confident in reading both types of texts after receiving the learning strategies training; however, most students still did not have much confidence to read the texts from Asian sources while some students enjoyed the challenge to read both rhetorical styles.

The texts from Asian sources made most of the students feel anxious because text written in the Asian rhetorical style tends to begin with specific details before introducing the main idea. Therefore, the readers need to read a lot of details first; with a risk they can get confused, before they see the main idea. So, this sometimes made them a little anxious. Also, the coherence of forms was not shown up precisely to the readers, and they had to interpret the text through the context; nevertheless, the students tried to read the whole texts successfully, as indicated by their statements such as Pimrose said "I have more confidence reading the deductive Western style than the inductive Asian style."

Some students enjoyed the challenge of reading both texts. This stimulated them try to read all the paragraphs in the Asian style to try and find all the main points of the texts. Therefore, they were not overly concerned about the rhetorical inductive style, with one stating, for instance, Suzie said "I had to repeatedly read the text several times in the inductive style but I think this was a challenging task for me."

\section{Motivation}

Although most students still worried to read the Asian inductive style, all of them recognized the importance of partici- 
pating in English classes and paid attention when participating in the class, as well as applying their new knowledge to other class, which was reflecte in statements such as Jerry said "I wished to study further to improve my skills and develop my language proficiency to an advanced level.

Interestingly, when the students received more practice, they learned to adjust themselves to read both deductive and inductive styles successfully, as reflected by their statements such as Jesica said "My reading ability for both text types tends to increase."; Kathy "I think that I become an active reader and I dare to share my ideas with friends."; Tanya said "I believe that my reading skills are improving all the time despite the fact that my language proficiency seems to remain at a medium level."; Beauty said "When I read a lot of the texts, I found I could understand, analyze the rhetorical style of the texts and now I have more confidence, and also am not embarrassed to share my knowledge with the whole class."; Jerry said "When I study and practice using the strategies for reading frequently, it makes me more confident, to a certain extent."

In addition to the information above, this part revealed that the students who preferred reading with their friends and who sometimes felt anxious when reading Asian texts were mostly those students with language proficiency around a medium and low level, albeit a few high-proficiency students felt similar. On the contrary, the students who liked the challenge of reading the texts in different styles and who liked to read independently maintained a high proficiency level

To sum up, every student improved their self-efficacy in reading and understanding both rhetorical styles - Western and Asian - and they gained positive motivation from attending and participating in the reading classes; however, their reading behaviors for reading different texts were different for the different styles, whereby they needed repeat readings and to take a lot of time for understanding text written in the Asian style. Further, most students gained more confidence about reading texts written in the Western style and liked to read the texts together with their friends, same way as for reading texts written in the Asian style. On the other hand, some students liked the challenge to read the different styles and to read independently, even with taking more time and using reading repetition with the texts written in the Asian style. Overall, all of them had higher self-efficacy believes than in the past and this also supported their increased positive motivation to study English further.

\section{DISCUSSION}

This study aimed to investigate Thai students' self-efficacy (SE) beliefs in EIL textual reading before and after receiving training in appropriate learning strategies. According to Chularut and DeBacker (2004), Khajavi and Ketabi (2012), and Mastan and Maarof (2014), such learning strategies can support EFL and ESL students to improve their SE beliefs in English language training. Such learning strategies have also been applied in previous studies to facilitate students' SE beliefs to support learning and the teaching of EIL. The findings challenged the idea and revealed that applying a learning strategies model could increase the students' SE in EIL textual reading performance. This section discussed some of the benefits and limitations of this model; however, the strength part was mostly discussed, such as the approach toward the learning strategies training model and appropriate reading materials, including the students' SE with a variety of rhetorical styles used in different texts from different sources and countries. These were discussed as follows:

\section{Training Approach}

This way of providing learning strategies training is referred to as explicit/direct instruction and practice (Cohen, 2003, cited in Ellis and Shintani, 2014). Then, it was important for the teacher to decide the appropriate training steps to apply before implementing the learning strategies training model with the class. This study focused on step-by-step practice guided by language-rhetorical learning strategies, including presenting a relevant thinking process, together with using several strategies applied to the different reading tasks set for the class. The students could gain more benefits from these training steps.

On the contrary, regarding its limitations, if the teacher does not set in place an appropriate training process for the students on how to use learning strategies for useful language learning, then the students might not succeed in improving their language use. Simultaneously, the model included both direct and indirect strategies to motivate the students to gain more knowledge of both English language and rhetorical styles. If the teacher does not well prepare appropriate lesson plans, they may face some problems because of the different language proficiencies of the students in a mixed-ability classroom. So, the teacher needs to aware of the students' differences in order to develop an effective approach to the students' training and to stimulate them in the classroom to apply these strategies to a real-world context, i.e. without teacher supervision.

\section{Learning Strategies Model and Selection of Reading Materials}

Since the learning strategies in previous studies were mostly presented in terms of their good function, this study inevitably focused on their benefits; however, this was different from previous studies because the learning strategies were developed in this study with an aim to improve the students' performance in terms of both language and rhetorical comprehension, which no previous study covered. Besides, when the students gained more knowledge and practiced frequently, sustainable learning was possible through applying the learning strategies they were taught. This was not only concerned with what they learn but also how they learn.

In terms of the reading materials, these were selected in accordance with the students' requirements and to fit in with the course curriculum as well as to suit the integration of EIL learning and the desired teaching approach. Significantl , the selection of instructional materials needed to encourage students' interests in order to stimulate the students' to learn effectively. 


\section{The Students' Se with a Variety of Rhetorical Styles.}

Most students experienced a little anxiety and needed to discuss the text with their friends while reading texts written in the Asian style, while some students liked the challenge and liked to read independently. In such cases, the learning strategies affected the students' SE. At the same time, this study involved a mixed-ability class and focused on a variety of texts. These reflected the different attitudes of the students. In line with second language acquisition (SLA) theory, individual learners needed different learning approaches and attitudes.

\section{CONCLUSION AND SUGGESTION}

The present study developed a learning strategies model to promote students' self-efficacy (SE) beliefs in EIL textual reading. Students who received training in rhetorical-language learning strategies (RLLSs) to assist reading in EIL lessons reported improved SE beliefs in EIL textual reading. Although most students still did not have much confidence to read the texts from Asian sources, all of them recognized the importance of attending and participating in the English classes as well as applying the knowledge and skills in other class.

To contribute to the efficacy of EIL learning and teaching, the teachers are able to promote the teaching of learning strategies to students to encourage and support them to read successfully, underlining the paradigm of EIL. Previously, language-learning strategies (Oxford, 1990, 2001) have supported students already with a good performance in reading. Crucially here, rhetorical strategies are utilized to help the students comprehend and become more aware of different cultures through reading.

\section{ACKNOWLEDGEMENTS}

I would like to express my sincere thanks to Dr. Anamai Damnet as the principal supervisor for advising me how to conduct this research successfully and encouraging me how to become a good researcher totally.

\section{REFERENCES}

Bandura, A. (1997). Self-efficacy: The exercise of control. New York: Freeman.

. (1998). Personal and collective efficacy in human adaptation and change. In J. G. Adair, D. Belanger, \& K. L. Dion (Eds.), Advances in psychological science: Vol. 1. Personal, social and cultural aspects (pp. 51-71). Hove, UK: Psychology Press.

Bembenutty, H. (2009). Academic Delay of Gratification, Self-Efficac , and Time Management among Academically Unprepared College Students. Psychological Reports, 104 (2), 613-623.

Braun, V. and Clarke, V. (2006) Using thematic analysis in psychology. Qualitative Research in Psychology, 3 (2), 77-101. http://eprints.uwe.ac.uk/11735.

Brown, H. D. (2007). Principles of language learning and teaching. USA: Pearson Education.
Chan, J. C. Y., and Lam, S. F. (2010). Effects of different evaluative feedback on students' self-efficacy in Learning. Instructional Science, 38, 37-58.

Chularut, P., and T. K. DeBacker. (2004). The Influence of Concept Mapping on Achievement, Self-Regulation, Self-Efficacy and in Students of English as a Second Language. Contemporary Educational Psychology, 29, 248-263.

Cohen, A. D. (2000). Strategies in learning and using a second language. Beijing: Foreign Language Teaching and Research Press.

Educational Testing Service. (2003). TOEFL Practice Test. http://www.toefl.o g/copyright.html.

Ellis, R., and Shintani, N. (2014). Exploring Language Pedagogy through Second Language Acquisition Research. NewYork: Routledge

Ghonsooly, B., and Elabi, M. (2010). Learners' Self-efficacy in Reading and its relation to Foreign Language Reading Anxiety and Reading Achievement. Journal of English Language Teaching and Learning, 53, 217.

Graham, S. (2007). Learner Strategies and Self-Efficacy: Making the Connection. Language Learning Journal, 35 (1), 81-93.

Khajavi, Y., and S. Ketabi. (2012). Influencing EFL Learners' Reading Comprehension and Self-efficacy Beliefs. Porta Linguarum, 17, 9-27.

Li, Y., and Wang, C. (2010). An empirical study of reading self-efficacy and the use of reading strategies in the Chinese EFL context. Asian EFL Journal, 12(2), 144-162.

Margolis, H., and McCabe, P. P. (2006). Improving self-efficacy and motivation: What to do, what to say. Intervention in School and Clinic, 41(4), 218-227.

Mastan. M. E., and Maarof. N. (2014). ESL learners' self-efficacy beliefs and strategy use in expository writing. Procedia-Social and Behavioral Sciences 116, 2360-2363.

McKay, S. L. (2002). Teaching English as an International Language. Oxford: Oxford University Press.

Naseri, M. and Zaferanieh, E. (2012). The Relationship between Reading Self-efficacy Beliefs, Reading Strategy Use and Reading Comprehension Level of Iranian EFL Learners. World Journal of Education, 2 (2):64-75.

Ngoksimma, S. (2014). A Study of Learners'Beliefs about English as a Foreign Language Learning of Grade 9 English Program (EP) Students in Pathum Thani. (Master Thesis).

O'Malley, J. and Chamot, A. (1990). Learning Strategies in Second Language Acquisition. Cambridge: Cambridge University Press.

Oxford, R. L. (1990). Language learning strategies: What Every Teacher Should Know. Boston, Massachusets: Heinle and Heinle Publishers, a Division of Wadsworth, Inc.

Oxford, R. L. (2001). Language learning styles and strategies. In M. Celece-Murcia (ed). Teaching English as a Second or Foreign Language. Boston: Heinle \& Heinle. Thompson International, 359-366.

Pajares, F., and T. Urdan. (2006). Self-Efficacy Beliefs of Adolescents. Greenwich, CT: Information Age. 
Raoofi, S., B. H. Tan, and S. H. Chen. (2012). Self-efficacy in Second/Foreign Language context. English Language Teaching, 5(11), 60-73.

Riding, R.J., and Rayner S.G. (2001) Self Perception (International Perspectives on Individual Differences). Westport, CT: Ablex.

Siritararatn, N. (2013). English Self-Efficacy Beliefs of EFL Low Proficiency Graduate Students. Academic Journal of Interdisciplinary Studies, 2(3),

Suwantharathip, O. (2012). The effects of reading strategies based on collaborative learning approach on EFL stu- dents' reading comprehension. European Journal of Scientific Research, 88(1), 11-27.

Wang, et al. (2013). Self-Efficacy and Self-Regulated Learning Strategies for English Language Learners: Comparison between Chinese and German College Students. Journal of Educational and Developmental Psychology, 3(1), 173-191.

Zimmerman, B. J. (2000). Self-Efficacy: An Essential Motive to Learn. Contemporary Educational Psychology, $25,82-91$. 